\title{
Social-economic effects of the COVID-19 pandemic in Lithuania
}

\author{
Migle Černikovaité ${ }^{1, *}$, Žaneta Karazijienè ${ }^{2}$ \\ ${ }^{1}$ Mykolas Romeris University, Institute of Communication, Ateities St. 20, 08303 Vilnius, Lithuania \\ ${ }^{2}$ Vilnius Gediminas Technical University, Faculty of Business Management, Department of \\ Economics Engineering, Saulètekio ave. 11, 10223 Vilnius, Lithuania
}

\begin{abstract}
.
Research background: COVID-19 pandemic became the global issue in today's world. Due to the globalized world, the virus had a possibility to spread across the globe and infect people from different nations and continents. However, COVID-19 pandemic is the consequence of globalization that has tremendous social-economic outcomes around the globe. COVID-19 also induced the panic in mass media and governments adopted new policies and precautions in order to minimize the damage and spread of this virus. However, due to the government restrictions, the consumer behavior also had a drastic change and influenced the economy as a whole.

Purpose of the article: To investigate the social-economic effects of COVID-19 pandemic in Lithuania.

Methods: scientific literature analysis, statistical analysis of secondary data and comparative analysis.

Findings \& Value added: People are well informed about the COVID-19 pandemics in Lithuania. Thread of COVID-19 was seen as real and Lithuanians were in panic that affected their behaviour on purchasing consumer goods and services. Lithuanian economic sectors were affected differently. However, Lithuania has a mild social-economic effects of COVID-19, were more concerned about global issues related to the virus (spreading globally and in Europe, impact on economy and etc.) and less about personal, local and national issues (closure of Lithuanian borders, closure of schools and universities, crisis in tourism and other sectors).
\end{abstract}

Keywords: COVID-19 pandemic; social-economic effects; globalisation effects; panic behaviour

JEL Classification: $A 11 ; E 7 ; F 60$

\footnotetext{
*Corresponding author: $\underline{\text { miglec } @ \text { yahoo.com }}$
} 


\section{Introduction}

Relevance of the study: The COVID-19 pandemic has caused a major shock to the global economy. Millions of COVID-19 cases, growing hospitalisation rates, including overwhelmed hospitals in some countries, as well as a shortage of equipment and supplies prompted policymakers to take stringent measures to contain the spread of the virus. The threat of the pandemic and government restrictions led to an enormous slump in global economic activity, disruptions in production and supply chains, a fall in international trade flows as well as a decline in consumer and business expectations. The world's major economies failed to avoid a huge downturn despite large-scale fiscal stimulus and monetary policy measures that had been put in place. In the second quarter of 2020, the US economy plunged by more than $9 \%$ year-on-year, whereas the euro area and the UK recorded annual declines of $15 \%$ and more than $20 \%$ respectively. Nonetheless, the easing of restrictions on mobility and business across countries triggered some recovery in global trade, activity and economic outlook.

Assessing the social-economic effects in European countries after COVID-19. The euro area has been hit harder by the pandemic than other economic areas around the world. Latvia, Lithuania and Finland suffered less. At the same time, Spain, France and Italy, the countries most affected by the pandemic in the Eurozone, tend to have different problems in different regions. Why have the Baltic and Nordic countries suffered less than Southern Europe? Closure and quarantine have been much stricter in this region, industry has been more affected, and tourism has come to a complete halt, as Spain, France and Italy are highly tourist destinations. The crisis in the Baltic States is not as deep as elsewhere in the world, as the situation in the Baltic States was better than elsewhere due to the fall in GDP that occurred in the first half of this year. Therefore, it is very important to find out what determined the positive effect of Lithuania, COVID-19 socio-economic effect.

The object of the research is the assessment of socio - economic factors in the environment of globalization and global economy. Investigation problem. What factors are necessary to assess the impact of the COVID-19 pandemic in the global environment?

The aim of the work is to examine the importance of e - commerce in the global economic environment and to develop an e - commerce evaluation model based on different theories of valuation models and to explore its application in the global environment. Research aim is: to investigate the social-economic effects of COVID-19 pandemic in Lithuania.

Methods: scientific literature analysis, statistical analysis of secondary data and comparative analysis.

\section{The concept of globalization and the global economy}

Globalization creates new challenges and opens up more opportunities for business development. Opportunities to expand your business into new markets that were previously closed due to price regulation or other indirect barriers, as well as access to resources such as labor, capital, knowledge on a global scale. In the literature, the assessment of globalization stands out. Some authors argue that globalization is a positive phenomenon that opens closed borders and allows societies or states to learn from the experiences of other states and take from them what is best. However, some authors believe that the state itself no longer has its role in regulating the economic and social life of societies. For this reason, there is no common definition of globalization, different authors define the process of globalization differently, emphasizing the political, social, economic and cultural aspects of the process (see Table 1). 
Table 1. Definition of globalization.

\begin{tabular}{|c|c|}
\hline Author & Definition \\
\hline Hussain (2018) & $\begin{array}{l}\text { Globalization is a process in which goods, labor and capital markets } \\
\text { are integrated into the world economy. }\end{array}$ \\
\hline Ravallion (2018) & $\begin{array}{l}\text { Globalization can be defined as better economic integration between } \\
\text { countries, which means a greater degree of economic openness to } \\
\text { foreign trade and better movement of financial capital. }\end{array}$ \\
\hline Marginean (2015) & $\begin{array}{l}\text { Globalization is a process of accelerating and intensifying relations } \\
\text { and relations between business partners, which are closely related to } \\
\text { technological and economic factors. }\end{array}$ \\
\hline Gurgul and Lach (2014) & $\begin{array}{l}\text { Globalization means the unification of goods and capital markets } \\
\text { internationally, which facilitate the development of international } \\
\text { trade, and greater opportunities for foreign investment. }\end{array}$ \\
\hline Urbšienė (2011) & Globalization is a process of market integration. \\
\hline $\begin{array}{c}\text { Sliburyte and } \\
\text { Ostaseviciute (2009) }\end{array}$ & $\begin{array}{l}\text { Globalization is the development, intensification, deepening and } \\
\text { acceleration of all relations and connections in modern social life, on } \\
\text { a global scale, and is associated with the shrinkage and relative } \\
\text { disappearance of space and time, where advanced technologies and } \\
\text { communication networks affect neither information nor } \\
\text { communication. than events. At the same time, the interdependence } \\
\text { of communities in different regions of the world and the spill-over } \\
\text { effect are growing. }\end{array}$ \\
\hline
\end{tabular}

Source: compiled on the basis [3-5], [7], [10-11], [13], [16].

Globalization is an inevitable process that has both positive and negative consequences [11]. Globalization can be understood as promoting globalization and removing national borders, but at the same time threatening the existence of ethnic culture and local diversity [8]. Meanwhile, Karanassou and Sala, examining the topic of globalization, emphasizes that globalization can be understood differently [9]:

- From an economic point of view: it is a movement of international trade, free capital, human resources and technology that affects the global and regional economies. The author argues that the growth of international trade and capital flows relative to the state's national income can be understood as a process of economic globalization.

- In terms of market integration: The process of market integration occurs when the prices of the same product (for example: goods, labor or capital) in the markets converge geographically (price convergence occurs) or when the changes in these prices become more and more similar over time.

- Globalization - can be understood as the emergence of institutions regulating cross-border economic exchanges.

- From a social point of view: this is a social and political cross-border interaction. This may be related to the ideas of colonialism and imperialism, or to participation in international organizations to strengthen the level of civil society [9].

According to Šliburytė and Ostasevičiūtè, globalization means reducing and eliminating cross-border barriers in order to facilitate the movement of goods, capital, services and labor [13]. Meanwhile, Marginean argues that the concept of globalization covers many more areas than just the growing rates of international trade and foreign investment [7]. The internationalization of technology and the increasing flow of services are part of the changes in the globalization process. Gurgul and Lach argue that technological progress 
reduces the cost of transport, improves the flow of information, and influences economic and political changes, where the focus is on reducing protectionism and migration, liberalizing foreign investment [3]. According to Duernecker and Vega-Redondo, who have studied the globalization impact of social networks [5]. In a nutshell, this term refers to the process by which even agents who are geographically far apart come to interact, thus being able to overcome what would otherwise be a fast saturation of local opportunities. A key feature of our model is that the social network is the main channel through which agents exploit new opportunities.

This means that the possibilities for nation states to organize separate economic and political life are gradually diminishing. Thus, globalization helps countries to move from individual national economies to a global economy in which goods are sold internationally and financial transactions between different countries take place quickly and smoothly. [2]

Totonchi and Manshady have examined in detail the relationship between globalization and social-economic effects [15]. It was found that the process of globalization and technological change have laid the foundations for the emergence of a new global economy based on knowledge and information. The study revealed that globalization helps to strengthen a company's existing competition and helps to expand it internationally, enables businesses to compete with global companies in international markets. Business development across borders involves many more internal processes. Aydin and Savrul also examined the relationship between economic development and globalization [1]. The authors argue that the transition to a new form of economy based on knowledge and information has helped to remove time and space constraints, while also providing an opportunity to reduce production costs. Malecki and Moriset also examine the topic of whether globalization contributes to the faster and more efficient development of ecommerce, or whether e-commerce nevertheless accelerates the process of globalization [6].

By summarizing it can be said that the processes of globalization have a huge impact on all areas and processes of life. Globalization can be defined as a dynamic phenomenon that has given businesses more opportunities. It has become easier for businesses to establish themselves in global markets: the removal of time and space constraints has made it easier for businesses to cooperate internationally and increase the number of consumers. It can be said that one of the essential consequences of globalization is a global economy, which is based on the global connection between economic factors and markets.

\section{Research methodology}

For a comprehensive assessment of globalization, it is useful to elucidate the application of empirical methods used in the scientific literature. The analysis of scientific articles has shown that in practice there has been little research on relevant statistics in a global environment. The main reason for this is the rapidly changing information and lack of data. Most studies only assess socio-economic indicators, but pay little attention to assessing psychological, technological or financial consequences in a global environment. It has been observed that empirical research uses research methods such as statistical and comparative analysis, as well as multicriteria evaluation.

In order to fully assess globalization trends, benefits for business and the global economy as a whole, a statistical analysis of EU countries is carried out, which assesses five dimensions:

- Emotional, where the proportion of the country's population that has changed its consumption behavior during the analyzed period and started to buy goods using ecommerce. 
- Technological, where the availability of the Internet, the frequency and duration of Internet use, the number of start-ups, the number of employees working in them and the increase in turnover are assessed.

- Socio-economic, which assesses COVID-19's contribution to gross domestic product (GDP), inflation, unemployment and other factors.

For detailed analysis of static data, calculations of growth rates, averages, and relative values are provided. The following formulas are used for the calculations:

The indicators of increase (change) rates are intended to show the rate of change of the studied phenomenon [2]. It is the ratio of the absolute change to the time series value, which shows the percentage increase or decrease in the value of the respective attribute in a later period (compared to the baseline). The growth of a given indicator $\mathrm{x}$ in year is defined by the formula:

$$
x_{t}=\frac{\left(Y_{t}-Y_{t-1}\right)}{Y_{t-1}} \times 100 \%
$$

This formula shows the percentage change in the real indicator between year's $\mathrm{t}$ and $\mathrm{t}-1$.

According to Seilius, Šimanskienè. he sample average is calculated according to a formula [12]:

$$
\bar{x}=\frac{1}{n} \sum_{i=1}^{n} x_{i}
$$

where - number of values.

The analysis is performed on the basis of data provided by EUROSTAT, the Department of Statistics of the Republic of Lithuania and the Bank of Lithuania and the Ministry of Finance of the Republic of Lithuania.

\section{Empirical research results}

The e-commerce evaluation model developed in the theoretical part includes factors divided into five dimensions that examine the emotional state of customers (consumer confidence and satisfaction with e-commerce), technological characteristics (level of Internet accessibility, security and privacy), socio-economic , contribution to GDP and the impact of e-commerce revenues on the company's total turnover), Statistical analysis of these factors will help to assess COVID - 19 effects on a global scale in Lithuania.

\subsection{Psychological factors}

During the pandemic, it was observed that the pandemic caused by COVID-19 or the corona virus causes anxiety for many Lithuanians, creating more stress in our daily lives. Concerns have been raised not only about the health and likelihood of infection for oneself or loved ones, but also about the socio-economic consequences of the pandemic. Because we feel unable to plan and control the situation in the unknown, we can overreact to the stress we experience - stockpiling what we don't need, constantly reading information about the victims of the virus and its spread, intimidating and intimidating others.

The global pandemic and quarantine measures have undoubtedly led consumers to turn even further to e-shops. For its buyers, it was often the only safe way to purchase the goods they needed. However, even after the reopening of the doors of physical stores, 
Lithuanians did not give up the advantages of online shopping, and they plan to continue actively buying online.

A study conducted in EU showed, that are among the most likely to shop online in Europe. About half (48\%) of Lithuanians say that even after the restrictions related to Covid-19 were lifted, most of their purchases were made online. Only Greeks (51\%) and Poles (58\%) were more likely to express this position in Europe. For comparison, only 28 percent. Latvians, 39 percent. Estonians and an average 37\% ofEuropeans plan to buy most of their purchases online after the pandemic. For businesses, this has undoubtedly provided new opportunities and encouraged investment in the development of e-commerce. It is likely that the new consumer habits formed during the pandemic will continue and in the long run will lead to further e-commerce growth of the trade sector.

The changes in consumers and businesses associated with the pandemic highlight other effects. There are fewer and fewer cash payments, which is increasing the importance of payment cards. Many buyers use credit to pay - they buy with borrowed money, which shows the importance of financial literacy in society. A very attractive solution when shopping today and settling later or over a longer period of time with poor personal financial planning can have negative long-term consequences. In summary, the tendency of people in individual countries to buy online also depends to a large extent on factors such as a developed Internet infrastructure, cyber security and efficient delivery logistics, therefore in countries where more attention is paid to these areas, e. the trade sector may have even better prospects.

\subsection{Technological factors}

The global pandemic has provided many opportunities for technology companies to develop innovative products. The fastest volumes and exports of telecommunications, computer and informatic services during the pandemic. even 53\%. Sales revenue of Lithuanian start-ups that quickly adapted to the situation during the first half of 2020 was $30 \%$ higher than in 2019, and the number of employees and their salaries also increased. And in terms of start-up income, which in the first half of 2020. grew to 242 million. euro Exports of start-ups in Lithuania grew by $16 \%$. At that time, exports of goods and services of the total economy fell by $10 \%$, while sales revenue fell by $5 \%$. The study of COVID- 19 revealed that the ability of start-ups to quickly adapt and offer to the market the products that are most needed at the moment: these are various solutions related to the challenges of the pandemic to society, business and the state. Lithuanian statutes currently employ 9,000 people employees. The gross salary amounted to EUR 2,600, which is more than the market average of other sectors.

\subsection{Socio-economic factors}

According GDP forecast (-2.0\% in 2020), the damage sustained by Lithuania's economy has so far been relatively moderate. Overall, the economic contraction in 2020 will be less pronounced than previously expected thanks to more favourable economic dynamics, less severe labour market conditions and additional fiscal, regulatory and monetary policy measures rolled out to support the economy. According to current forecasts, growth trends for the year to come should unfold in a similar vein - Lithuania's real GDP is projected to increase by $3.1 \%$ in 2021 . 


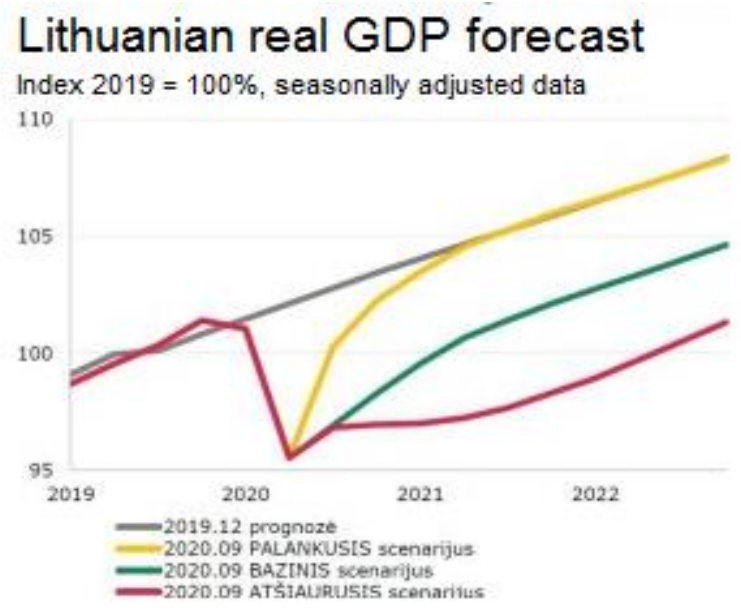

Fig. 1. GDP forecast for Lithuania in short-term.

According to the economists of the Bank of Lithuania, in the case of the main scenario, the economy will shrink by $2 \%$ this year. The economic downturn is projected to be smaller than in 2020 and the projected recovery in 2021 will be more moderate, with GDP expected to grow by $3.1 \%$ next year. However, the uncertainty about the consequences of the pandemic for the economy remains high, therefore the Bank of Lithuania has assessed both the harsh scenario: in 2020, GDP will shrink by 2.4 percent, and next year it will not grow, and the favorable scenario will be -0.2 and +5 percent, respectively.

The economy will benefit substantially from fiscal measures, which may add 2.3 percentage points to the country's GDP growth in 2020 and 2.6 percentage points in 2021 . These forecasts have been underpinned by the assumption of potential resurgence in COVID-19 infections in Lithuania and the rest of the world, which, however, this time round would not entail stringent virus containment measures, such as a nationwide lockdown. Scientists are not expected to introduce a medical solution to the general public before 2021, which implies that growth is set to be constrained by high epidemiological and economic uncertainty (see Table 2).

Lithuania, as one of the most open economies, is driven by exports. And while export growth has fallen slightly in recent months as a result of the pandemic, a major drama has been averted, with exports declining by only $2.4 \%$ (excluding oil products). Not only that, the fact that Lithuanian industrial personnel is quite diversified by countries and goods contributed to this. Lithuania does not depend on any market or on the small list of exported products, and over the past 10 years we have been able to expand high-tech industry and trade and have received foreign investment in those areas.

Weakening external demand has weighed on Lithuania's exports of goods and services, yet there already are some signs of recovery. The pandemic and its containment measures introduced by the governments of Lithuania's major export partners have led to a significant drop in external demand. As a result, Lithuania's real exports of goods and services slumped by more than $8 \%$ year-on-year in the second quarter of 2020 . 
Table 2. General statistics of Lithuania and it's projections

\begin{tabular}{|c|c|c|c|}
\hline & \multicolumn{3}{|c|}{ September 2020 projection } \\
\hline & 2019 & 2020 & 2021 \\
\hline \multicolumn{4}{|l|}{ Economic activity (constant prices; annual changes) } \\
\hline Gross domestic product & $3.9 \%$ & $-2.0 \%$ & $3.1 \%$ \\
\hline Private consumption expenditure & $3.2 \%$ & $-2.4 \%$ & $3.9 \%$ \\
\hline General government consumption expenditure & $0.7 \%$ & $0.3 \%$ & $0.3 \%$ \\
\hline Investment & $7.3 \%$ & $-7.7 \%$ & $6.4 \%$ \\
\hline Exports of goods and services & $9.6 \%$ & $-3.8 \%$ & $6.9 \%$ \\
\hline Imports of goods and services & $5.9 \%$ & $-6.1 \%$ & $8.4 \%$ \\
\hline \multicolumn{4}{|l|}{ Labour market } \\
\hline $\begin{array}{l}\text { Unemployment rate (annual average a share of labour } \\
\text { force }\end{array}$ & $6.3 \%$ & $8.8 \%$ & $8.1 \%$ \\
\hline Employment (annual change) & $0.3 \%$ & $-1.5 \%$ & $0.6 \%$ \\
\hline \multicolumn{4}{|l|}{ Price and cost developments (annual changes) } \\
\hline Average annual inflation, as measured by the HICP & $2.2 \%$ & $1.0 \%$ & $1.2 \%$ \\
\hline GDP deflator & $3.0 \%$ & $0.7 \%$ & $1.4 \%$ \\
\hline Wages & $8.8 \%$ & $6.8 \%$ & $3.1 \%$ \\
\hline Import deflator & $-0.6 \%$ & $-5.5 \%$ & $1.3 \%$ \\
\hline Export deflator & $0.8 \%$ & $-4.1 \%$ & $0.8 \%$ \\
\hline
\end{tabular}

Source: The bank of Lithuania [2]

Even though the labour market took a turn for the worse, unemployment rose less than projected, with its rates going up by mere 2.4 percentage point's year on-year, to reach $8.5 \%$ in the second quarter. A larger increase in unemployment was stifled by better economic releases, government support to the country's corporate sector affected by the pandemic and the rebound in economic activity. The more positive economic situation also suggests that the labour market development in the projection horizon should be more favourable than previously anticipated, and the economic recovery should send the unemployment rate on a downward path as early as at the end of 2020 .

The average wage in the country should increase by $6.8 \%$ in 2020 due to this year's hike in the minimum wage, rapid wage growth in the public sector and better than expected economic performance. Private consumption is projected to shrink by a meagre $2.4 \%$ in 2020 and rise by $3.9 \%$ in 2021 , i.e. less than previously expected, due to the higher comparative base. Investment has been hit by both the pandemic and the EU Mobility Package. In the second quarter of 2020, investment volumes in Lithuania fell by more than $11 \%$ year-on-year. The downward effect on private investment from the pandemic and the prolonged economic uncertainty was exacerbated by developments in the transport sector, triggered by the gradual rollout of the EU Mobility Package. As a result, investment in vehicles plummeted by an annual $75 \%$ in the second quarter of 2020 . During the projection horizon, weak demand, heightened uncertainty and shrinking financial resources of the 
country's corporate sector are expected to further weigh on investment growth in the private sector. At the same time, public investment should boost investment growth thanks to the fiscal measures adopted by the authorities. However, a less effective than expected use of fiscal stimulus funds may bring up certain challenges. Investment is projected to decrease by $7.7 \%$ this year, before rebounding to $6.4 \%$ in 2021 (Bank of Lithuania, 2020).

Weaker economic activity and lower energy prices will exert downward pressure on consumer prices. With the world still battling the pandemic, prices of crude oil and food commodities are projected to remain depressed this year, which will continue to dampen inflation. Next year, however, the recovery of global economy should accelerate the rise in crude prices. Meanwhile, the expected slower wage growth should diminish pressure on prices of services - the average annual growth in prices of services is projected to decelerate to $4 \%$ in 2020 , whereas in 2021 it should increase at a rate slightly above $2 \%$. Average annual inflation is expected to be $1.0 \%$ in 2020 and to reach $1.2 \%$ in 2021 .

In summary, this was largely due to the rapid response of Lithuanian governments, which helped us survive the first wave. Elections in Lithuania may be the reason why the government wants to support the economy. This may be the reason why the Government is more willing to spend money and support the economy. Researchers of the Ministry of Finance of the Republic of Lithuania pointed out that although the recovery is fast in many areas, the transport sector will lag behind for some time. Good news for Lithuania - the debt of our countries was lower than elsewhere in Europe. Governments are giving a huge boost to our economy unless there is a second wave that would severely disrupt the recovery and countries have to close again, then the level of government debt we forecast should remain below the euro area average in 2019 and significantly lower average in 2020 and 2021.

\section{Conclusions}

1. The analysis of scientific literature was performed in order to examine the processes of globalization and their impact on the socio-economic environment of the country.

2. Finds that there is no general definition of globalization, as globalization is a phenomenon of social and economic activity that can be perceived subjectively and defined differently. Globalization is a dynamic phenomenon that has been marked by technological progress and digitalisation, which has opened up more opportunities for businesses to operate in the international market. The process of globalization and technological change have laid the foundations for the emergence of a new global economy based on knowledge and information. The advent of technology has given businesses more opportunities to establish themselves in global markets: the removal of time and space constraints has given businesses the opportunity to collaborate and compete with global companies in international markets. Globalization processes have been found to have contributed to changes in socio-economic countries.

3. Empirical studies have found the damage of COVID-19 sustained by Lithuania's economy has so far been relatively moderate. Overall, the economic contraction in 2020 will be less pronounced than previously expected thanks to more favourable economic dynamics, less severe labour market conditions and additional fiscal, regulatory and monetary policy measures rolled out to support the economy.

4. Today, it is becoming clear that all the challenges facing our planet are common. War, wherever it occurs, is a problem for everyone, as are global economic crises, the spread of a global pandemic, demography, migration, physical and mental health, and ecological problems. If we do not want these problems to be solved, to lead to a dystopian dictatorship model of society or perhaps to the destruction of humanity, we must work hard to find a way for nations and communities to solve problems together. The case of Lithuania showed 
that the ability to coordinate the problems regulating COVID-19 consecuences, solved by the consensus of governments and communities is a way out of any crisis.

\section{References}

1. Aydın, E., Savrul, B. K. (2014). The Relationship between Globalization and Ecommerce: Turkish Case. Procedia - Social and Behavioral Sciences, 150, 1267-1276.

2. Broner F.,Ventura, J. (2016). Rethinking the Effects of Financial Globalization. The Quarterly Journal of Economics, 131(3), 1497-1542.

3. Gurgul, H., Lach, Ł. (2014). Globalization and economic growth: Evidence from two decades of transition in CEE. Economic Modelling, 36, 99-107.

4. Hussain, M. (2018). Globalization and Foreign Trade of Pakistan with D-8 Group. Journal of Business Theory and Practice, 6(2), 133.

5. Duernecker G., Vega-Redondo F., (2017) Social Networks and the Process of Globalization. The Review of Economic Studies, 85(3), 1716-1751.

6. Malecki, E. J., Moriset, B. (2007). The Digital Economy: Business Organization, Production Processes and Regional Developments. Routledge Taylor \& Francis Group.

7. Mach, L. (2019). Measuring and assessing the impact of the global economic crisis on European real property market. Journal of Business Economics and Management, 20(6), 1189-1209.

8. Mittelman, J. H. (2014). Interview James H. Mittelman. Globalizations, 11(4), 549559.

9. Karanassou, M., Sala H. (2020). Distributional Consequences of Technology, Trade Globalisation and Financialisation in the US. Economic and Social Review, 51(2), 275303.

10. Ravallion, M. (2018). Inequality and Globalization: A Review Essay. Journal of Economic Literature, 56(2), 620-642.

11. Santos, B. D., B. (2006). Globalizations. Theory Culture \& Society, 23(2-3), 393-399.

12. Seilius, A., Šimanskienè, L. (2006). Management of business organizations in the context of globalization: theoretical approach. Business: Theory and Practice, 7(4), 213-221.

13. Sliburyte, L., Ostaseviciute, R. (2009). Theoretical Aspects of Economic Globalization Impacts on Emerging Economies. Economics \& Management, 14, 947-953. Retrieved from: https://ecoman.ktu.lt/index.php/Ekv/article/view/9496

14. Stiglitz J.E (2000). The Contributions of the Economics of Information to Twentieth Century Economics. The Quarterly Journal of Economics, 115(4), 1441-1478.

15. Totonchi, J., Manshady, K. (2012). Relationship between Globalization and ECommerce. International Journal of e-Education, e-Business, e-Management and eLearning, 2(1), 83-87. Retrieved from: http://www.ijeeee.org/Papers/085Z00068T889.pdf

16. Urbšienè, L. (2011). The concept of globalization: Contemporary approaches. Business: Theory and Practice, 12(3), 203-214.

17. Broner, F., Ventura, J. (2011). Globalization and Risk Sharing. The Review of Economic Studies, 78(1), 49-82.

18. Statistical department of Lithuani (2020). Statistics of COVID-19 impact. Retrieved from:https://www.stat.gov.lt/en_GB/home//asset_publisher/lbrXvLVHX2ln/content/id/ 8041989 